\title{
Isomorphic and Allomorphic Features of Iconic Units \\ (Based on Turkish Onomatopes)
}

\author{
Anna V. Krasnova* \\ St. Petersburg State University of Economics \\ 21 Sadovaya Str., St. Petersburg, 191023, Russia
}

Received 11.12.2017, received in revised form 05.02.2018, accepted 12.02.2018

Despite the long history of studying the iconicity phenomenon, the onomatopoeic and sound symbolic words have acquired the status of linguistic universal in a relatively recent past. In the Turkish linguistic tradition, the question of iconic vocabulary was addressed within the framework of morphology, while the question of correlation between the meaning of a unit and its acoustic image stayed in the background. In the middle of the twentieth century, researcher S.V. Voronin made a clear distinction between units that reflect a sound and those which sphere of motivation in a broad sense can be formulated as a non-acoustic, and also proposed his own classification of iconic elements based on the type of the reflected sound. This classification principle made it possible to apply the classification to analyse iconic vocabulary of any language of the world, and also to reveal isomorphic and allomorphic features of the given units of the language considered in comparison with the canonical types indicated in the classification.

Keywords: language universals, language sign, iconicity, sound symbolism, onomatope, Turkish language, phonosemantics.

DOI: 10.17516/1997-1370-0219.

Research area: philology.

\section{Introduction}

Throughout the history of the evolution of linguistic science the question of the correlation between the meaning of the word and the sound was and still is the most discussed and along with this controversial issue in the field of the philosophy of language. To this day in linguistics there is no unified opinion on this issue. From the time of Ancient Greece, the opinions of researchers differed, and the philosophers divided into two camps: "naturalists" who believed that the meaning of words is connected with the form "by nature" (phýsei), that is, due to the internal correlation between the form and the meaning, and "conventionalists" who claimed that the meaning is arbitrary and based on a social agreement (thései). Both theories find supporters among outstanding linguistic scholars. The principal supporter of the thései theory was F. de Saussure, who, as is known, considered the "arbitrariness of the linguistic sign" as one of the fundamental features of linguistic systems.

(C) Siberian Federal University. All rights reserved

* Corresponding author E-mail address: annekrasnova@gmail.com 
Other prominent scientists considered the issue of iconic units in their works from the point of view of the phýsei theory.

Due to the small amount of practical material and authority of F. de Saussure the "conventional theory" dominated in linguistic science for a long period of time. It is also worth noting that in the early stages of emerging interest to iconic vocabulary, before phonosemantics stood out as a separate discipline, the iconic units were considered very rare and unproductive in terms of word formation. Further studies of scientists (Voronin, 2006, Bartashova, 1987, Flaksman, 2015) showed the fallacy of this statement. In the $20^{\text {th }}$ century, a large volume of accumulated practical material and theoretical studies made it possible to distinguish phonosemantics as a separate area of field of studies within linguistics, thereby enabling a deeper and more focused study of the phenomenon of onomatopoeia and sound-symbolism.

Although linguistic studies in this field of research date back to the Ancient times iconic units have been viewed as language universal only in the second part of the $20^{\text {th }}$ century.

\section{Theoretical framework}

It would be incorrect to argue that all languages contain in their vocabularies only phonetically motivated or, on the contrary, unmotivated words. Both of these categories of words take their place in language systems in various languages in different proportions. S. Ullman notes that in English and other languages, words can be motivated in three different ways (Ullman, 1963/1966):

1) Morphologically motivated (when the meaning of the whole word can be determined by the meaning of individual components of the word);

2) Semantically motivated (new words are formed using a transparent metaphor);
3) Phonetically motivated (the sounds themselves represent a direct imitation of the corresponding action).

Iconic units belong to the third type of motivation. S. Ullman calls the morphological and semantic motivation secondary, while the phonetic one is primary, since the correlation between the phonetic features of the word and the meaning is direct. According to the scientist, "phonetic motivation seems to occur in all languages", in other words, it can be recognized as "absolute" linguistic universal (Greenberg, Osgood, Jenkins, 1963). It is important to underline that the "absolute" universals are absolute not in the literal sense of the word "absolute", but only conditionally, since it is barely possible to prove the existence of any universal in all languages at all stages of the development of these languages. "Absolute" universals are those universals that can be observed in a very large number of languages. We can never persuasively prove that these phenomena are omnipresent or "panchronic" (Ullman, 1970).

Despite the fact that iconicity is a linguistic universal, the sounds of the surrounding reality and the features of various objects can be realized in different ways in practice in different languages, due to differences in grammars and phonetic tools. For example, in many languages the expression of the idea of "small" is realized by means of a consonant /i/ (English: little, slim, thin, wee, teeny-weeny, French petit, Italian piccolo, lat. minor, minimus, Greek mikrós, Hungarian kis, kicsi, pici, etc.). However, in many languages one can find examples in which the given consonant is found in words having the opposite meaning (English: big, big, great). Nevertheless, one can observe a phenomenal similarity between the sound-symbolic and, in particular, the onomatopoeic words of different languages. 
Tackling the problem of iconicity in Turkish, a superficial knowledge of the language makes it possible to notice the presence of a sufficiently large number of iconic words. Due to certain abnormal phonetic and morphological characteristics of this layer of vocabulary iconic units could not fail to become the object of numerous linguistic studies, both in Turkey and abroad. However, despite the extensive material for analysis, there are not many systematic studies of the phenomenon of iconicity. These studies, as a rule, have a descriptive character and cover only narrow areas mainly in the light of reduplication (Ağakay, 1953; Tuna, 1949) or in connection with the question of the ontogenesis of the language (Üçok, 1947; Başkan, 1948).

In Soviet science, the main contribution to the study of the iconic words of Turkish and Turkic languages was made by Soviet turkologists Professor N.I. Ashmarin and N.K. Dmitriev. The study of the Turkic iconisms began, in fact, with the publication in 1918 in Kazan of the work of prof. N.I. Ashmarin "Fundamentals of the Chuvash Mimology". Before this publication, such works were extremely few; they did not possess not only a clear program and the purpose of research, but also extensive systematic material. N.I. Ashmarin was the first scientist who introduced the concept of "mimes". In his work, the professor laid the theoretical foundations and gave a practical classification of mimes. The first detailed description of the iconic vocabulary of the Turkish language was given by the Soviet Turkologist N.K. Dmitriev in his work "Structure of the Turkic Languages" in the chapter "To the Study of Turkish Mimology", based on the work of N.I. Ashmarin. N.K. Dmitriev accepted the classification and terminology of the professor and for his own independent research. Under the term "Mimology" N.K. Dmitriev meant the entire sphere of imitative words; a word that represents imitation he called a "mime", i.e. all iconic words in general, both sound-symbolic and onomatopoeic units. For onomatopoeic words, he used the term onomatopoesia (Dmitriev, 1962: 59).

N.K. Dmitriev proposed his classification of mimes and also compiled a brief dictionary of iconic words. All the mimes, depending on the source of the sound, he divided into the following categories: sound imitations (pit pit "sound of steps"), imitation of the phenomena of light and movement (pirlldamak "to parkle, to shine"), imitation of phenomena occurring in the living body (slzı "nagging pain"), imitation of baby language (tototo "children's babble").

In Turkish linguistic tradition the most systematic research of iconic units belongs to Hamza Zülfikar. In his book "Türkçede Ses Yansımalı Kelimeler" he emphasized abnormal phonetical and morphological features of Turkish iconic units that make them odd ones out in the language corpus. In the research he made an attempt describe how exactly phonetical tools of the language corrrelate with the reflected sound (for example, plosive consonants $b / p / k$ reflect the sounds of explosions, ticking, clicking, in other words, any sounds that are perceived by human hearing as an acoustic shock). The scientist also proposed his own classification. While N.K. Dmitriev created his classification based upon the sourse of sound, H. Zülfikar categorised iconic units according to their morphology. He divided iconic vocabulary into three hyperclasses: primary sound imitations (birincil biçimler), the smallest indivisible monosyllabic onomatopoeic units ( $c a z$ "the sound of the sizzling droplets falling on a hot frying pan"); Secondary sound imitations (ikincil biçimler), formed by affixation of primary sound imitations ( $m$ lşll mışıl "imitation of snoring"); sound imitative derivatives (türevler biçimler). Can be formed from primary and secondary sound imitations in different configurations: with the help of various 
types of reduplication or affixation (haykırmak "to scream").

Despite the fact that the above mentioned classifications offered a detailed description of iconic units and shed light onto their morphological features, some aspects of iconic units were out of focus of the studies. First of all, the researches didn't make a clear distinction between sound imitative units that only reflect sounds and sound simbolic units that imitate phenomena of non-acoustic nature. Secondly, the aspect of correlation of sound and phonemes reflecting the sound was left in the shadow of morphology. Furthermore, the morphological grounds of the classification make it very specific and unapplicable to other languages. According to S.V. Voronin, "Any classification designed without taking into account acoustic characteristics of various types of reflected sounds is inevitably subjective and incomplete" (Voronin, 2006: 39). S.V. Voronin was one of the first researches who made a clear distinction between sound imitative units and symbolic ones and designed his own classification of sound imitatives based on acoustic parametres of the reflected sounds.

Despite the fact that the original classification was based on English, Bashkir and Indonesian languages, certain classes and types of onomatopes can be found in other languages. Thus, this classification is universal. On the basis of this classification, the researcher established the basic phonosemantic universal, which is that there are three classes (instants, continuants, frequentatives) and two hyperclasses of onomatopes (instantantcontinuants and quasiinstants continuants) in the iconic vocabulary of any language of the world (Voronin, 2006). The universal classes are the following:

1) Instants as a class of onomatopes reflect sound of strokes, hits and are one of the most numerous classes of imitations in different languages. In Turkish there are the following examples of this class of onomatopes: pit pit "imitation of the trampling"; tik tak "imitation of the clock ticking";

2) Continuants as a class of onomatopes reflect a coherent tone or noise sound. In the Turkish language continuants are represented by the following units, for example, uğultu "hum", melemek "to bleat";

3) Frequentatives reflect very fast sequences of acoustic shocks and thus convey a dissonant sound. İn the Turkish language these units can be shown in the following examples: şlkırtı "crunch", şırll şırll "sound of running water".

This classification can be used to describe iconisms in any language and can help identify allomorfic and isomorphic features of iconisms compared to the equivalent units in the other languages. The above mentioned clasess and hyperclasses are also present in the Turkish language. Although the classes are universal, there can be some difference in combination of phonemes used for reflection various types of sounds.

\section{Peculiarities of onomatopes in the Turkish language}

\section{Class A. Type I. Instants}

Instants represent a class and at the same time a type of onomatopoeic words, denoting "ultra-short" noise or tone sounds perceived by a person as an acoustic schock (Voronin, 2006: 46). This type of onomatopes refer to such types of sounds as different types of strokes, knocking, ticking, clicking, etc. More intense sounds, as a rule, are reflected by open vowels in the root of the onomatope, less intense by close ones. The most typical consonants in these onomatopes are occlusive consonants usually explosives in the position of the beginning and the end of the word. However, there are a few onomatopes with 
an initial occlusive-constrictive consonant, for example in English ( jab, jabber, jit, jog).

In Turkish language the most significant component of the onomatope in terms of iconicity is the root of the iconic unit, while the affixes are grammatical markers indicating the part of speech the word belongs to. These affixes in most cases do not contain significant imitative phonetic elements. The exceptions are the affixes -ll (-ll, -il, -ul, -ül), -lr (-lr, -ir, -ur, -ür), as confirmed by many researchers, for example, A.M. Gazov-Ginzberg, who notes that the $l, r$ consonants in different languages are often found in the suffixes of the iconic words. For example, in Turkish language these affixes are "ultimate distinguishing features" for sound-imitative and sound symbolic words (Gazov-Ginzberg, 1965: 159). As a rule, these RL-formants in Turkish and many other languages perform the function of repetitivness of the action the word describes (Likhomanova, 1986; Bartko, 2002).

In Turkish, as in many other languages, the basic elements of the root, reflecting the qualitative parameters (instantaneous short blow, click) of the sound, are the plosive phonemes /p/, /b/, /t/, /d/, /k/, /g/. Thus, the instant pit is an acoustic imitation of the light sound produced when a small object falls onto a nonresonant surface, for example, pit ptt "sound of falling drops of water", pitır pitır "sound of footsteps, sound of some small fruit falling to the ground".

The initial consonant in most onomatopes of this type in Turkish is a plosive consonant, however, one can find rare sound imitations with an initial occlusive nasal sonant (mık mık/mıkır mıkır "an imitation of intense boiling", mıkıld "a sound of stirring of something fluid and soft") or a constrictive sonant (luk luk "imitation of boiling", loplatmak "to punch", yepelemek "to pat on the back"). Onomatopes containing these types of phonemes, as a rule, refer to less distinct and weaker sounds than units with an initial plosive consonant.

Voiced and voiceless affricates can also be incorporated into a root of an instant onomatope in the Turkish language. Onomatopes containing a voiceless affricate in the initial position in their root structure usually reflect muffled and quiet sounds that occur when some light objects collide against each other or break, for example, in the words with the meaning of a crunch (çat "imitation of crunching when breaking something dry", çatapat/çatıpatı "a cracker, a firecracker", çat çat "sound when falling or hitting something", çatılamak "to clap,to click", çıt/çıt çıt "sound when breaking something dry", çıt çıkarmamak "not to make any sounds", çıt etmek/çıtlamak "to crunch when breaking", çıtıltı "a crunch", çıtıldamak "to make sounds when walking on something dry", çıtpıt "cracker"). Also, a voiceless affricate can be found in imitations of the sounds of strikes or collisions occurring in a sound absorbing environment, for example, in the words denoting gurgling, bubbling and other sounds in the aquatic environment (çalk çulk "a sound of objects colliding against each other", çalk çulk çalkalamak/çalkmak "to shake up, to whip", çalkalama "whipping", Çalkantı 1)" heaving of the sea, 2) something whipped (for example, scrambled eggs). Voiced affricates, on the contrary, serve to transmit the sounds of loud sounds emited by heavy objects colliding against each other or hitting the resonating surface ( $c a b$ cup "imitation of splashing", cabildamak "to emit sounds when hitting hard objects", cabirtl "a sound from hitting two hard objects against each other", cabll cubul "a sound when moving under water", cabbalamak "to shake something liquid", cibban çalmak/cibbelek çalmak/cibiciklemek "to clap, to applaud", cibilemek "to swim, to splash", cibtirmek "to chop" cibll cıbıl etmek "to wash", cıbildamak "to extract sounds when colliding under water"). 
The vowel in this type of sound imitative units, depending on the parameters of the reflected sound, can be either high or low, but always short, since in the native Turkish words there are no long vowels or two vowels standing side by side. (Genish, 2010: 31). The babbling of birds are often encountered among these class of onomatopes and demonstrate a typical picture of an acoustic shock (cik cik etmek/çikgildemek "to twitter", cikilti "a noise emitted by birds or insects", cikcik/cikciki "a gold-crested wren", dakllamak "to chirp (about a patridge)", dakır dakır "imitation of knocking or clicking"). In some cases the vowel can be followed by a sonant (bulk bulk etmek "to bubble", bulkümek "to emit gases", bulkamak "to rot, to swell, to bubble", bulkak "swollen", çalk çulk çalkalamak/çalkmak "to shake up, to whisk”, büngül büngül çıkmak "to spurt").

In the structure of Turkish instant onomatopes there is never a confluence of consonants in the initial syllable, since this combination of phonemes is impossible for the native words of the language due to its phonotactics and can only be found in borrowings. The only exception is the syllable bre. The confluence of consonants in any other part of the word is also not typical, with the exception of the morphological seam between the root morpheme and the affix (Genish, 2010: 43). In the final position of the words the plosive consonant is the only possible phoneme for the Turkish instants. The structural model of the instant onomatopes in Turkish for roots, having the form CONS + VOC + CONS, can be represented the following way:

\section{CONS + VŎC $C^{\mathrm{L} / \mathrm{H}, \mathrm{s} / \mathrm{w}}$ (+SON) + PLOS.}

It is worth noting that the above features of Turkish instants are not unique exclusively for the Turkish language. When considering examples of onomatopes of this class in other languages, it is not difficult to establish the obvious presence of certain universal features.

Here are some examples of instants from different languages. English: blop, bat, chip, cackle, chack, chop, clap, gaggle, knock, pat; Indonesian: detap "knocking", bobok "a sound when putting an empty bottle into water"; Bashkir: bult-bult "a sound of a liquid leaking out of a bottle", kelt-kelt "ticking" (about clocks); Japanese: tataku (compare with the Turkish taka tuk "an imitation of a knock"), doka-doka "a sound of a knocking"; Nanai: tep-tap "an imitation of water dripping"; Khmer: kyp "an imitation of the knocking of an ax".

As can be seen from the examples, this type and at the same time class the sound imitative units most clearly demonstrate isomorphic features. It is important to underline that typologically different languages contain in their vocabularies imitations built on almost identical models. According to the classification of S.V. Voronin, the universal canonical model, reflecting the most significant features of this type of onomatopoeic words of English, Bashkir and Indonesian languages, looks as follows:

\section{PLOS/AFFR + VŎC $\mathrm{C}^{\mathrm{L} / \mathrm{H}, \mathrm{S} / \mathrm{W}}+$ PLOS.}

As far as could be seen from the examples above Turkish onomatopes have a lot in common with the equivalents from the other languages in terms of structure and elements reflecting certain types of sounds. As well as Englih, Khmer or İndonesian sound imitations, Turkish onomatopes tend to express knocking, clicking or ticking sound with plosive consonants sharing therefore strong universal features. However, unlike English iconisms, Turkish onomatopes do not use long vowels to reflect the intensity of the sound due to natural phonotactical limitations of the language making these types of phonemes impossible. 


\section{Class B. Continuants}

As a class of onomatopes, continuants reflect long-lasting sounds that can be both tone and noise. This class of onomatopes includes several types of sounds: tonal continuants (type II), pure-noise continuants (type II) and noise tonal continuants (type III) (Voronin, 2006: 48).

\section{Type II. Tonal continuants}

Tonal continuants reflect a pure tonal sound without any other types of sounds (ibid.). In Turkish, units of this type can reflect a fairly wide range of sounds, the only unifying feature of which is the reflection of a tone. A large number of units belonging to a given class of onomatopes imitate sounds produced by living beings and also include a variety of different zoonims, ornithonims and insectonims. In order to transmit this type of sound the Turkish language possesses a wide range of phonetically significant elements that are manifested in onomatopes depending on the qualitative characteristics of the transmitted sound. Thus, in onomotypes imitating low-frequency tonal sound one can often find the vowels $/ \mathrm{u} /$ and $/ \mathrm{o} /$, for example, in imitation of humming (uğultu "hum, deaf sound", uğuldamak "to make low, booming sounds, to buzz", bögürmek "to roar (about an animal)", anırmak "to bray (about a donkey)", as well as in imitations of some birds and in the names of animals, insects and birds (guggu/ gugguş "an owl”, gugo "a cuckoo", übübuk "a gold-crested wren", bubuh "an owl”, ankirheci "a donkey", bübürdek "a nightingale"). This type of onomatopes also includes the names of wind musical instruments (düdük "a pipe, a whistle"). In imitations of high-frequency sounds (chirping of birds, squealing, etc.) the function of reflecting a tonal sound is usually realized by the vowel /i/, for example, in words such as siğilemek "to yip (about a dog)", inilemek/inil inlemek/inim inim inlemek/inlemek "to moan").
It should be noted that whereas in many languages the vowel in this type of onomatopes is long (as, for example, in English - cheep "to squeak"), in Turkish the longitude of a tone is not reflected in the vowel length, which is due to the peculiarities of the phonological system of the language. There are no long vowels in the Turkish language. The length of the vowels has been preserved mainly in Arabic and Persian borrowings and can be indicated with the help of diacritical signs (Genish, 2010: 28). In the native Turkish words, the longitude of sounds is realized exclusively by means of the letter $\breve{g}$ that is itself a silent letter, but makes the vowels before it long. Examples of such long vowels approximating tone sound can be observed in some onomatopes: klğırmak "to sing (about the rooster)", uğultu "hum". In other cases, where a soft $\breve{g}$ is absent, the external tonal sound is reflected with the help of a short vowel.

In order to reflect a tonal sound, several types of phonemes can be used in Turkish. The most frequent among the consonant sounds in the tonal continuant structure the composition are those that in their parameters are closest to the vowels that are nasal and constrictive sonants, as well as voiced fricatives. The sonant sonant $/ \mathrm{j} /$ can be noticed at the end of the root in combination with the previous vowel, as if extending the longitude of it, in imitation of animals (miyav "meow", sayramak "to sing, to twitter (about birds)", clyak "an owl", clynaklamak "to chirp (about birds)", baynamak "to sing (about a rooster)". Nasal sonants, due to their acoustic parameters, perform the function of reflecting the nonresonant tone (inilemek "to moan" çenlemek/cen cen itmek "to bark loudly"), just like the sibilants (zinilemek "to yip (about puppies)", sigilemek "to yip (about the dog)"). In general, the model of tonal continuants in the Turkish language can be represented as follows: 


\section{$\left(\mathrm{CONS}^{\mathrm{FRIC} / \mathrm{SIB}}+\right) \mathrm{VOC}^{\mathrm{L} / \mathrm{H}, \mathrm{S} / \mathrm{W}}+\mathrm{SON}^{\mathrm{MED} / \mathrm{NAS}}$ FRIC $\operatorname{VOC}^{\mathrm{L} / \mathrm{H}, \mathrm{S} / \mathrm{W}}$}

Since this type of onomatopes has a wide spectrum of significant iconic elements to reflect tonal sounds in different languages, constructing the canonical model reflecting the features of tonal continuants for all or most languages of the world is an impossible task. In English, which was adopted by S.V. Voronin as a canonical language, this type of onomatopes has the following form:

\section{$\left[\right.$ CONS (+SON $\left.\left.{ }^{\mathrm{LAT} / \mathrm{LAB}}\right)+\right]+\mathrm{VŎC}^{\mathrm{L} / \mathrm{H}, \mathrm{S} / \mathrm{W}}+$ PLOS.}

Here are the most typical examples of tonal continuants in different languages: English: cheep, hoot, bleep; Bashkir: hajrau "to sing (about birds)", saj-saj "to squeal, to howl"; Indonesian: dengung, dengong "imitation of the buzz"; Tadjik: guvvas "buzzing, howling", Japanese: unaru "buzzing, howling". Imitations of a squeak: Buryat "piid", Burmese. "wiwi", Japanese "pi: (-pi)". Turkish tonal continuants, in contrast to the instants, show isomorphic features least clearly, due to the aforementioned variety of phonetic tools aimed at conveying tone. The similar elements that Turkish onomatopes of this type share with their equivalents from the other languages are the vowel / u / (for example, in imitation of hum and buzz), the vowel /i/ (in the imitations of high-frequency sounds, for example, squealing), as well as sonants.

\section{Type VI. Pure frequentatives}

This type of onomatopes, as it can be seen from its name, is the most refined type of the frequentative onomatopes, that imitate the dissonant sounds (i.e. the sound perceived by the human hearing as a series of strokes, trembling). In the Turkish language this type is represented by imitation of birds or insects that produce high- frequency sounds like chirping or screaking, for example, căğı că̆ır "imitation of warbling (birds)", cor cur "an imitation of chirping, water bubbling", crrltt "chirping", crrlamak/cur cur etmek "to chirp", curcur "a cicada", circurama "a dragonfly", curcır böceği/curlak/cırlangeç/ cırlangıç/cırlavık/cırlavuk "a cricket", cırllavuk/ cırlağan /cırlağuk "a cicada". Among the pure frequentatives one can also find imitations of tearing of the material cirlldamak/ciyırdamak "to tear", cirım cirım "torn into pieces", cirmak "to tear apart" cirrlld "a sound of tearing fabric", cirrlldamak"to emit cracking sounds when fabric is torn", imitations of water bubbling çur çur "imitation of the sound of a jet of milk pouring into a bucket (when milking cattle)", curcirin/ cürcür "diarrhea", curt etmek "to urinate", imitations of crackling and creaking sounds "cırmıkatmak/cırmıklamak/cırmuklamak/ cirnaklamak/curmılamak" to scratch with nails, cırnak "a claw", ciyir ciyir etmek "to squeak", carlltı "creak".

As can be seen from the examples above, all the onomatopes of this type demonstrate approximately the same feature of sound trembling. Each onomatope transmits a sound that represents a whole series of strokes, but as these strokes, as in the case of cricket chirping, occur in an extremely fast sequence, this sound is not perceived by a person as separate sounds, but as a single dissonant sound. The main element that characterizes pure frequentatives is the phoneme /r/ which reflects vibration, trembling, chirping, and other types of dissonant sounds. The main phonetically valent element (r) is found in the final position of the sound-imitative root in all the pure frequentatives presented in the language with rare exceptions. There is only one unit where the R-formant is outside the root in the affix - ciyir ciyir etmek "to squeak". Like many other types of onomatopes, pure frequentatives have the traditional structure for the Turkish 
iconic units - CONS + VOC + CONS. In general, the model of pure frequentatives in the Turkish language can be represented as follows:

$$
\left(\text { CONS) + VŏC } C^{\mathrm{L} / \mathrm{H}, \mathrm{S} / \mathrm{w}}+\mathbf{R}\right. \text {. }
$$

The canonical model of pure frequentatives based on English, Bashkir and Indonesian languages is as follows:

\section{$\left(\right.$ CONS+) R + VŎC $\mathrm{L}^{\mathrm{L} / \mathrm{H}, \mathrm{S} / \mathrm{W}}+$ PLOS.}

It is worth noting that unlike the canonical model, in Turkish units of this type, there is never an explosive consonant as the final element of the phonetically motivated root. However, despite this difference, the isomorphic features of this type of onomatopes are quite distinct when compared with similar units of other languages. The reflection of a fractional trembling sounds in various languages - Selkup "kar", Nanai “dur-r", "bator-bator". The imitation of fluttering in Zulu "brr, drr, mbrr, ndrr".

\section{Conclusion}

Thus, in the light of the above information, it can be concluded that the sound-imitative words of geographically and genetically distant languages have a number of common phonetic tools serving to convey certain types of sounds. Thus, the imitations of the Turkish language, like the imitations of other languages considered, use plosive sounds to transmit sounds of beats, constrictive sonant $/ \mathrm{r} /$ for imitation of trembling sounds, as well as sonants and vowels /o/, /u/ and /i/ for displaying low-frequency and high-frequency tone sound respectively. Nevertheless, Turkish onomatopes have a number of allomorphic features that distinguish them from imitations of other languages, for example, the absence of long vowels and the impossibility of confluence of consonants. These specific features of Turkish iconic units derive from the phonetic basis of the language and limitations imposed by phonotactics of the language.

In conclusion it should be mentioned that iconisms form a separate subsystem in a language that obeys its own laws that can be considered "wrong", from the point of view of the language itself. It should also be noted, however, that in languages where iconisms represent a small class of vocabulary (English, Russian), these units do not demonstrate special word-formation ways that would not be typical for the rest of the language units (Flaksman, 39), while in languages with multiple iconisms (for example, Japanese and Turkish), these lexical units demonstrate specific ways of word formation and stand out as a separate class within the language.

\section{References}

Ağakay, M.A. (1953). İkizlemeler Üzerine, In Türk Dili, 2 (16), 189-191.

Ashmarin, N.I. (1918). Osnovi chuvashskoi mimologii [Fundamentals of Chuvash Mimology], Kazan.

Bartko, N.V. (2002). Angliiskiye zvukoizobrazitelnie RL-glagoli: dissertatsiia na soiskanie uchenoi stepeni kandidata philologicheskikh nauk. [English Iconic RL-Verbs: Phonosemantic Analysis: Cand of Science (Philology) Thesis], Leningrad State University.

Başkan, Ö. (1968). İnsan Dilinin Doğuşu, In TDAY - Belleten, 143-156.

Bartashova, O.A., Beloglazova, E.V. (2011). Towards the Problem of Translatability of Phonetically Motivated Elements, In Journal of Siberian Federal University, 4 (10), 1385-1393.

Bartashova, O.A. (1987). Zvukoizobrazitelnost v terminologii (na materiale angliyskih morskih terminov: dissertatsiia na soiskanie uchenoi stepeni kandidata philologicheskikh nauk) [Iconicity in 
Terminology (on the Example of English Sea Terms): Cand of Science (Philology) Thesis], Leningrad State University.

Dmitriyev, N.K. (1962). Osnovy stroya turetskikh yazikov [Structure of Turkish Languages], Moscow.

Gazov-Ginzberg, A.M. (1965). Byl li yazyk izobrazitelen v svoikh istokakh? [Was Language Iconic in Its Origins?], Moscow.

Geniş, E. (2010). Grammatika turetskogo yazika: tom 1. [Turkish Grammar: Vol.1].

Greenberg, J., Joseph, H., Charles E. Osgood and James J. Jenkins (1963). Memorandum Concerning Language Universals, In Joseph H. Greenberg (ed.), Universals of Language, XVXXVII. Cambridge, MA: MIT Press.

Likhomanova, L.F. (1986). Semanticheskaya filiatsia angliiskikh zvukoizobrazitelnih glagolov dvizhenia: dissertatsiia na soiskanie uchenoi stepeni kandidata philologicheskikh nauk) [The Semantics of English Iconic Motion Verbs: Cand of Science (Philology) Thesis], Leningrad State University.

Tuna, O.N. (1949). Türkçede Tekrarlar I, TDED.

Flaksman, M.A. (2015). Diakhronitcheskoye razvitiye zvukoizobrazitelnoi leksiki angliyskogo yazika: dissertatsiia na soiskanie uchenoi stepeni kandidata philologicheskikh nauk [Diachronic Development of English Iconic Vocabulary: Cand of Science (Philology) Thesis], Saint-Petersburg State University.

Üçok, N. (1947). Genel dilbilim (Lengüistik). Ankara: TDCF Yayınları.

Ullmann, Stephen. (1963/1966). Semantic Universals, In Joseph H. Greenberg (ed.), Universals of Language, XV-XXVII. Cambridge, MA: MIT Press, 217-262.

Voronin, S.V. (2006). Osnovi fonosemantiki [Fundamentals of Phonosemantics], St. Petersburg: Lenand.

Zülfikar, H. (1995). Türkçede Ses Yansimali Kelimeler, Ankara: TDK, Ankara.

\title{
Изоморфические и алломорфические черты иконических элементов
}

(на материале турецких звукоподражаний)

\author{
А.В. Краснова \\ Санкт-Петербургский государственный \\ экономический университет \\ Россия, 191023, Санкт-Петербург, ул. Садовая, 21
}

Несмотря на давнюю историю изучения вопроса звукоизобразительности, звукоподражания, и звукосимволизмы приобрели статус языковой универсалии в относительно недавнем прошлом. В туреикой лингвистической традиции вопрос иконической лексики рассматривался в основном в рамках морфологии, в то время как вопрос соотномения значения единиць и её акустического облика оставался в тени. В середине двадиатого века исследователь С.В. Воронин провёл чёткое разграничение между единицами, отражающими звуковой денотат, и теми, чью сферу мотивации в широком смысле можно сформулировать как незвук, а также предложил собственную классификацию иконизмов на основании типа отражаемого звуча- 
ния. Данный принции классификации позволяет применять её для рассмотрения звукоизобразительных единии любого языка мира, а также выявлять изоморфические и алломорфические черты данных единии рассматриваемого языка в сравнении с каноническими типами, обозначенными в классификации.

Ключевые слова: иконизм, звукоизобразительность, звукосимволизм, фоносемантика, языковой знак, турецкий язык, языковые универсалии.

Научная спеииальность: 10.00.00 - филологические науки. 